\title{
The Effect of Different Proportions of Males and Females over the Chrysomya albiceps (Wiedemann 1819) (Diptera, Calliphoridae) Biotic Potential and Longevity Under Laboratory Conditions
}

\author{
Margareth Maria de Carvalho Queiroz, Rubens Pinto de Mello*, Nicolau \\ Maués da Serra Freire**
}

\author{
Laboratório de Biologia e Controle de Insetos Vetores, Departamento de Biologia *Laboratório de Díptera \\ **Laboratório de Ixodideos, Departamento de Entomologia, Instituto Oswaldo Cruz, Av. Brasil 4365, 21045 - \\ 900 Rio de Janeiro, RJ, Brasil
}

\begin{abstract}
Chrysomya albiceps specimens were derived from colonies kept under laboratory conditions. The oviposition period, total number of eggs-mass and the weight of the eggs-mass (averagelfemale) presented significant differences between colonies regarding the sexual ratio of Imale/lfemale (situation I), when compared to the other ratios (Imale/3female, situation II), (Imale/5female, situation III), (3male/lfemale, situation IV) and ( 5 male/lfemale, situation V). It was ascertained that the increase in the proportion of females, resulted in higher weight and greater number of ovipositions and lenghtening of the period of oviposition, leads to a decrease in their lifespan.
\end{abstract}

Key words: Chrysomya albiceps - blowfly - biotic potential - longevity

Among the various plagues that cause serious damage to cattle breeding, the blowflies deserve special mention, due to the fact that besides producing "maggots" on domestic animals (primary myiasis), they can invade necrotic tissues (secondary myiasis). The fly Chrysomya albiceps (Wiedemann) has great medical importance because it is the producer of primary myiasis and, more frequently, of secondary myiasis. However, its role is more significant as predator of other larvae of diptera in the culture medium (Zumpt 1965, Gagné 1981, Erzinçlioglu \& Witcombe 1983, Marchenko 1985), in addition to being a vector for pathogenic microorganisms (Greenberg 1971). C. albiceps is originally from Africa, the Mediterranean area and the Middle East (Gagné 1981) and in Brazil its occurrence was observed in the urban areas as well as in the rural areas, and forests (Avancini 1986).

Braack and Retief (1986) consider this species important in the spread and maintenance of the carbuncle caused by Bacillus anthracis in South Africa. According to these authors, the fly, after contacting the skeleton of animals killed by this disease, spread the disease onto vegetation by bacillus infected saliva droplets.

This work was supported by CNPq.

Received 17 July 1995

Accepted 11 December 1995
C. albiceps is a bisexual species, however the females reproduce themselves monogenically. The males cannot influence the sex of their offspring, and the regulation of the percentage of the sexes is effected at the populational level (Ullerich 1963). Queiroz (1991) observed that this species besides being bisexual and reproducing themselves monogenically, may originate, in a same generation, males as well as females.

The easy adaptation and vast geographic distribution reached by $C$. albiceps suggests that more studies relative to the species bioetiology are necessary. This study's aims was to identify the effects caused by the different sexual proportions over the biotic potential and the longevity of the adults, under laboratory conditions, in order to help the development of colonization techniques.

\section{MATERIALS AND METHODS}

The specimens used came from colonies kept under laboratory conditions and belonged to a second generation, in accordance with the methodology of Queiroz (1991). The experiment consisted of five situations, which corresponded to the following proportions of males to females: situation I: 10 males/10 females, situation II: 30 males/ 10 females, situation III: 50 males/ 10 females, situation IV: 10 males/30 females and situation V: 10 males $/ 50$ females.

Soon after emergence, the adults were separated by sex and grouped, according to the situations (three repetitions for each situation), in 
transparent polyethylene cylindric cages $(30 \mathrm{~cm}$ high $\mathrm{x} 12 \mathrm{~cm}$ diameter). The top and bottom halves of one side wall of these cages had an opening $9.0 \mathrm{~cm}$ in diameter, closed with a plastic sleeve. The top of the cage had nylon netting for ventilation and the base was made of styrene plates taped to the wall and lined internally with paper towels. The adults were fed on a 50\% honey solution and slightly decayed equine meat, placed on Petri plates $(4.5 \times 1.2 \mathrm{~cm})$, wrapped in pieces of nylon netting. The food was renewed daily. The putrid meat served as a stimulus and substratum for oviposition.

The masses of eggs were taken, weighed and transferred to the Petri plates $(4.5 \mathrm{~cm} \times 1.2 \mathrm{~cm})$ lined with filter paper and dampened with distilled water $(0.4 \mathrm{ml})$. After $24 \mathrm{hr}$, the evaluation of the viability of the masses of eggs was started, with the help of a stereomicroscope. The observations took place daily. The curves of survival for the males and females were represented by the distribution model of Weibull and described by Sgrillo (1982).

The experiment took place in climatic chambers at $27 \pm 1^{\circ} \mathrm{C}, 60 \pm 10 \% \mathrm{RH}$ and $14 \mathrm{hr}$ of photophase. Test $t$ was used for the statistical comparison between averages and proportions.

\section{RESULTS}

The males and females in situations I and V started copulating on the second day post-emergence, while in situations II, III and IV it occurred on the third day. Copulations took place up to six

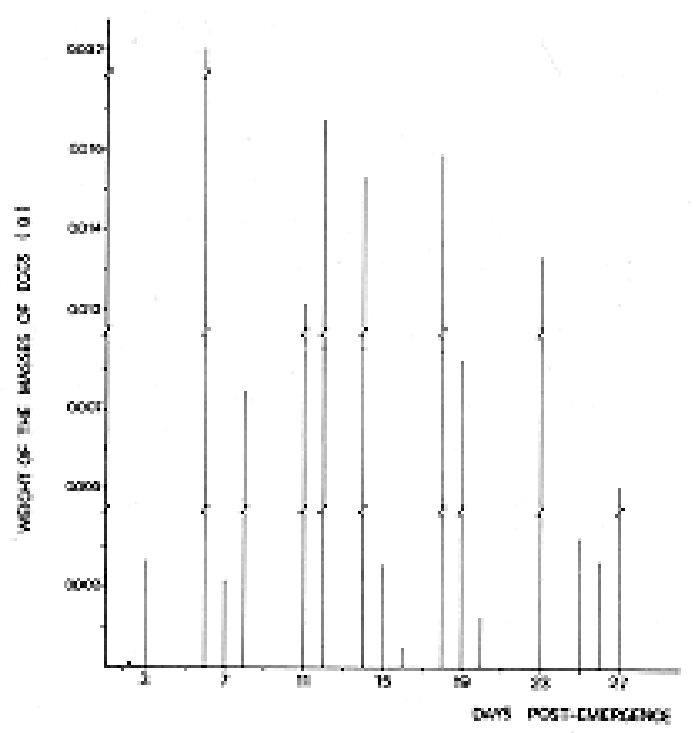

Fig. 1: egg-laying rhythm of Chrysomya albiceps (G2), with the ratio of 1 male: 1 female, under laboratory conditions $\left(27^{\circ} \mathrm{C}\right.$, $60 \pm 10 \%$ UR and $14 \mathrm{hr}$ photophase). days post-emergence.

The oviposition for situations I-V began on the 3rd, 7th, 5th, 11th and 4th day after emergence. The peak of oviposition for these (situations) and respective weights of masses of eggs/female, occurring on the 6th day $(0.032 \mathrm{~g}), 14$ th day $(0.041 \mathrm{~g})$, 17 th day $(0.021 \mathrm{~g}), 18$ th day $(0.081 \mathrm{~g})$ and $23 \mathrm{rd}$ day $(0.108 \mathrm{~g})$, respectively.

For situations I-V the length of egg-laying period was 24, 17, 18, 23, 32 days, respectively (Figs 1-5). The total number of ovipositions, the total average weight of the egg-masses, the average weight of the egg-masses per female and the viability of eggs for all situations are represented on the Table.

Some of the parameters analyzed in relation to the egg masses, taking as a reference the sexual ratio 1 male/1female (situation I) compared to the other proportions, showed significant differences, at a level of $1 \%$ (Table).

From the decrease in the male/female ratio resulted a higher weight and numbers of egg masses and lenghtened the egg-laying. The moderate increase in the male female ratio of $3 / 1$ resulted in an increase in weight of the egg masses, reduction of the oviposition period and number of egg masses. However, when the ratio of males was increased to five a reduction in the weight and the number of egg masses occurred.

Figures 6 to 10 present the curves of survival of males and females for each situation. However, the average longevity of the males and fe-

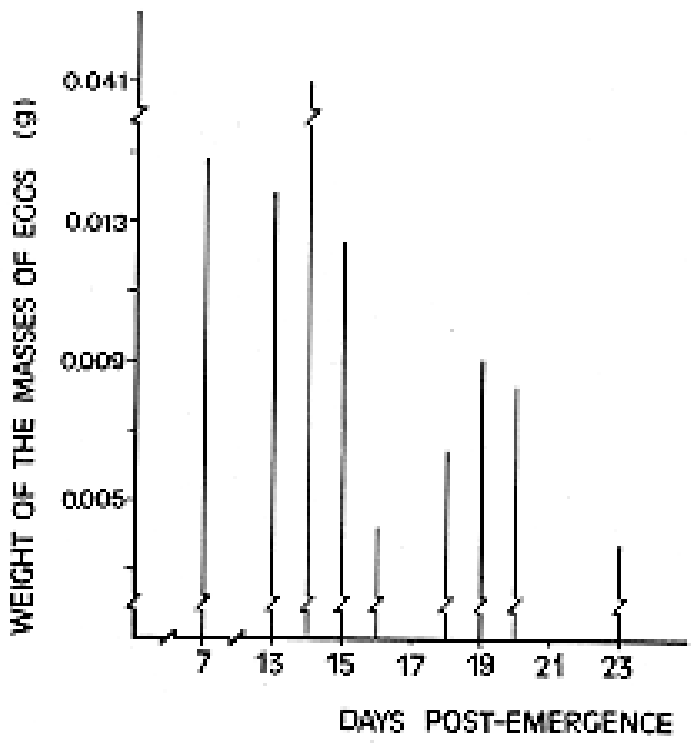

Fig. 2: egg-laying rhythm of Chrysomya albiceps (G2), with the ratio of 1 male: 3 females, under laboratory conditions $\left(27^{\circ} \mathrm{C}, 60 \pm 10 \%\right.$ UR and $14 \mathrm{hr}$ photophase). 


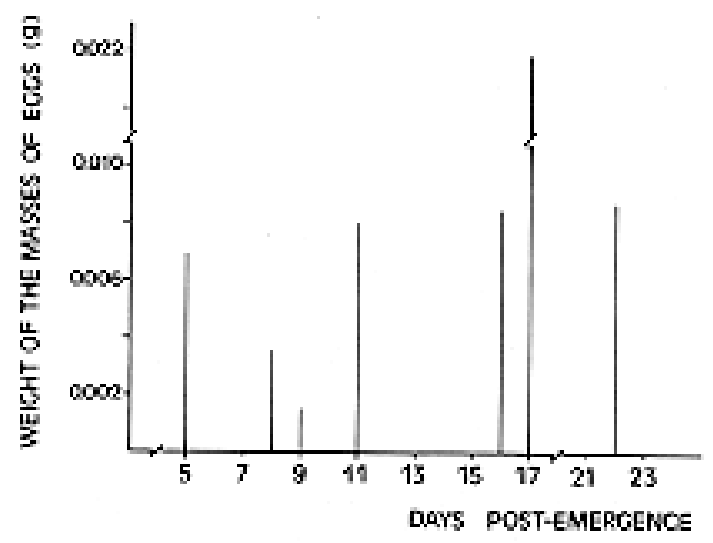

the ratio of 1 male: 5 females, under laboratory conditions $\left(27^{\circ} \mathrm{C}, 60 \pm 10 \%\right.$ UR and $14 \mathrm{hr}$ photophase $)$.

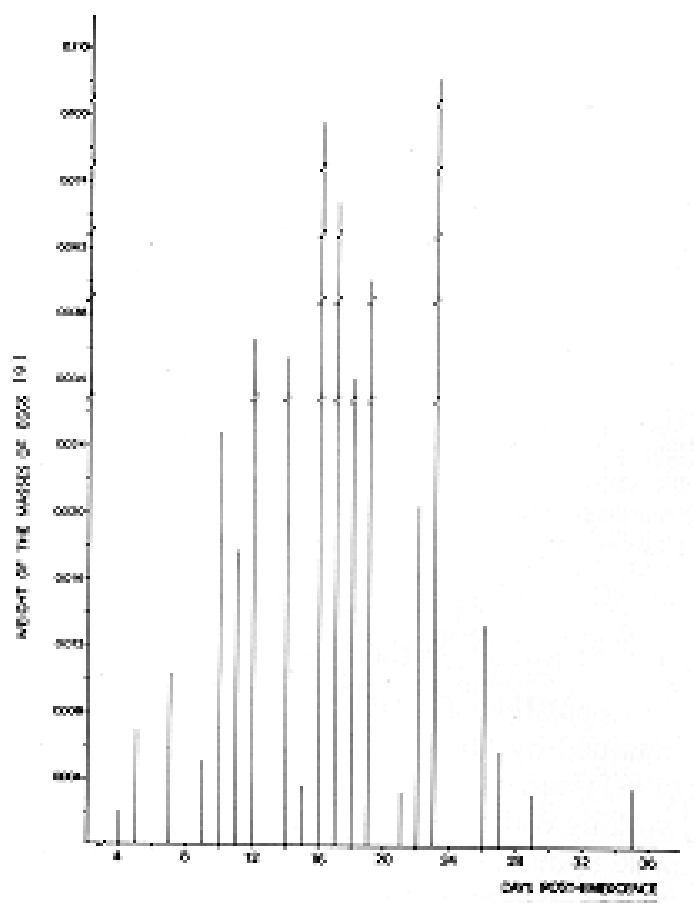

Fig. 5: egg-laying rhythm of Chrysomya albiceps (G2), with the ratio of 5 males: 1 female, under laboratory conditions $\left(27^{\circ} \mathrm{C}, 60 \pm 10 \%\right.$ UR and $14 \mathrm{hr}$ photophase).

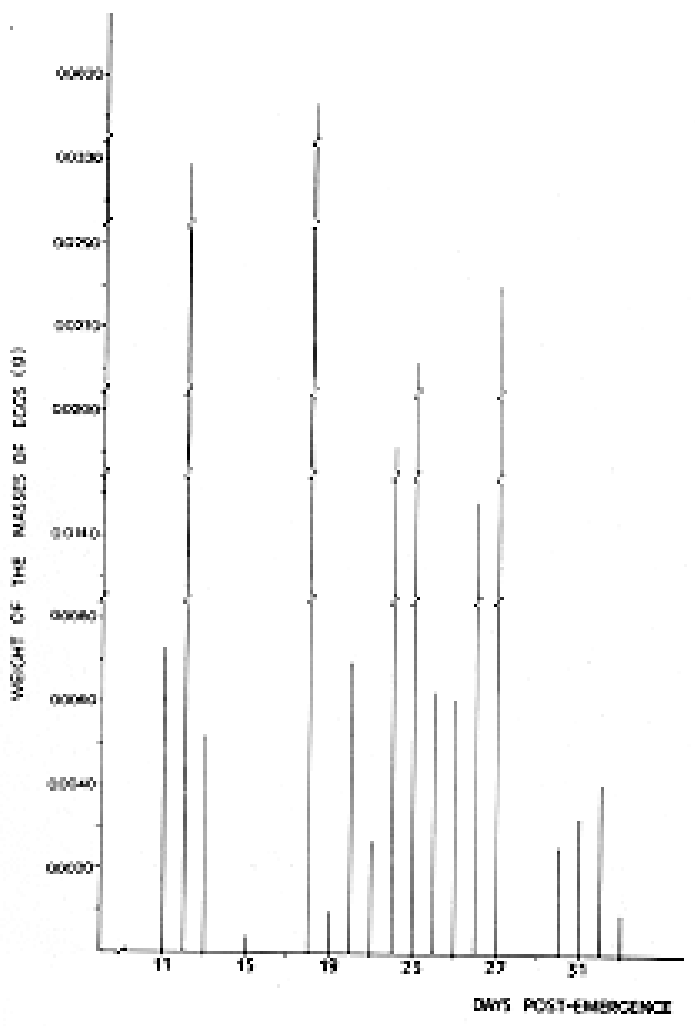

Fig. 4: egg-laying rhythm of Chrysomya albiceps (G2), with the ratio of 3 males: 1 female, under laboratory conditions $\left(27^{\circ} \mathrm{C}, 60 \pm 10 \%\right.$ UR and $14 \mathrm{hr}$ photophase).

males was of 7.5 and 17 days (situation I), 9.5 and 13.5 days (situation II), 9.5 and 12.5 days (situation III), 8.5 and 25 days (situation IV) and 5 and 19 days (situation V), respectively. The comparative analysis between the different situations showed that as the ratios became more unbalanced the sex with the least number of subjects experienced a relatively shortened lifespan.

TABLE

Breeding ability of Chrysomya albiceps, according to different sexual proportions $\left(27^{\circ} \mathrm{C} \pm 10 \% \mathrm{RH}\right.$ and $14 \mathrm{hr}$ photophase)

\begin{tabular}{|c|c|c|c|c|c|}
\hline \multirow[t]{2}{*}{$\begin{array}{l}\text { Sexual ratio } \\
\text { (male:female) }\end{array}$} & \multirow{2}{*}{$\begin{array}{l}\text { Period of } \\
\text { oviposition } \\
\text { (days) }\end{array}$} & \multirow[t]{2}{*}{$\begin{array}{l}\text { Total number } \\
\text { of egg-masses }\end{array}$} & \multicolumn{2}{|c|}{$\begin{array}{l}\text { Weight of egg- } \\
\text { masses }(\mathrm{g})\end{array}$} & \multirow[t]{2}{*}{$\begin{array}{c}\text { Viability of } \\
\text { eggs }(\%)\end{array}$} \\
\hline & & & $\overline{\mathrm{X}}$ (total) & $\overline{\mathrm{X}} /$ female & \\
\hline $1: 1$ & $25 \mathrm{a}$ & $16 \mathrm{a}$ & 0.1430 & $0.0143 \mathrm{a}$ & $95.82 \mathrm{a}$ \\
\hline $3: 1$ & $17 \mathrm{~b}$ & $9 \mathrm{~b}$ & 0.1140 & $0.0114 \mathrm{a}$ & $97.94 \mathrm{a}$ \\
\hline $5: 1$ & $18 \mathrm{~b}$ & $7 \mathrm{~b}$ & 0.0590 & $0.0059 \mathrm{~b}$ & $94.87 \mathrm{a}$ \\
\hline $1: 3$ & $23 \mathrm{a}$ & $18 \mathrm{a}$ & 0.2497 & $0.0008 \mathrm{c}$ & $92.01 \mathrm{a}$ \\
\hline $1: 5$ & $32 \mathrm{c}$ & $20 \mathrm{a}$ & 0.5712 & $0.0114 \mathrm{a}$ & $97.89 \mathrm{a}$ \\
\hline
\end{tabular}

Similar letters in the same column indicate differences which are not significant $(\mathrm{P}>1 \%, \mathrm{t}$ Test). 


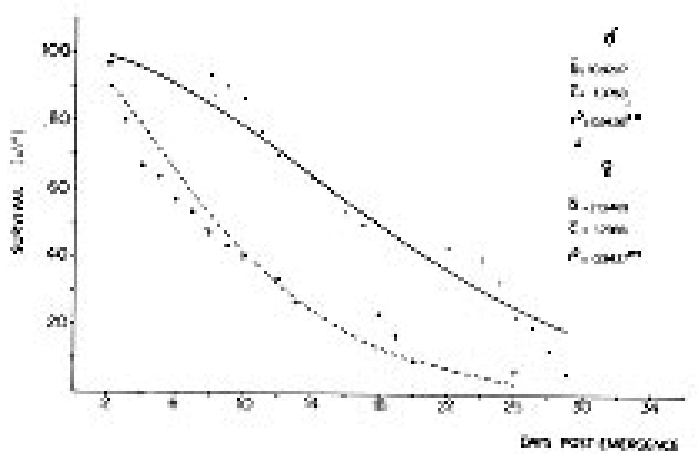

Fig. 6: males survival curve [observed (+); awaited (-)] and female Chrysomya albiceps $\left(\mathrm{G}_{2}\right)$ [ observed (..); awaited (-), the sexual proportion of 1 male/1 female being kept under laboratory conditions $\left(27^{\circ} \mathrm{C}, 60 \pm 10 \%\right.$ UR and $14 \mathrm{hr}$ of photophase).

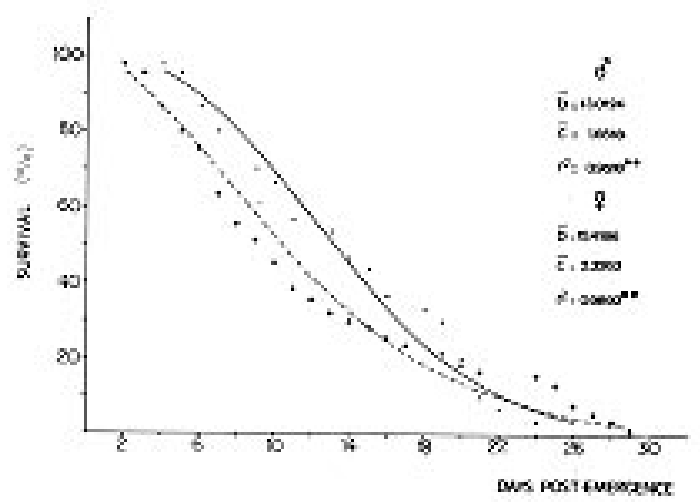

Fig. 7: males survival curve [observed (+); awaited $(-)$ ] and female Chrysomya albiceps $\left(\mathrm{G}_{2}\right)$ [ observed (..); awaited (-), the sexual proportion of 3 male/1 female being kept under laboratory conditions $\left(27^{\circ} \mathrm{C}, 60 \pm 10 \% \mathrm{UR}\right.$ and $14 \mathrm{hr}$ of photophase).

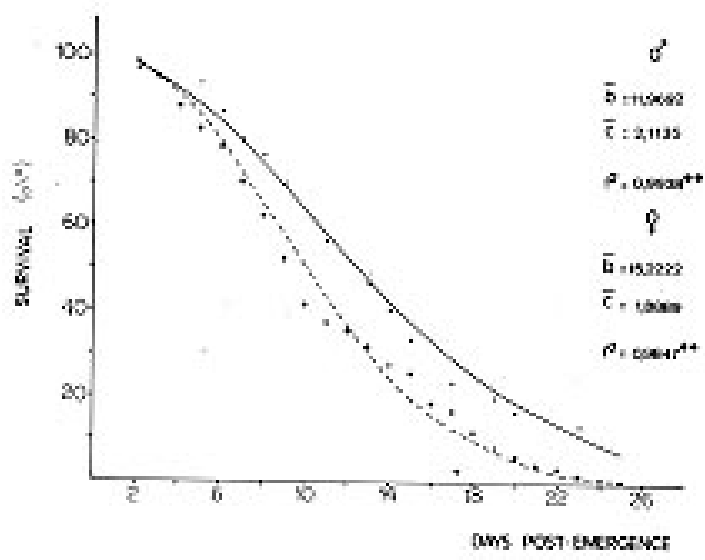

Fig. 8: males survival curve [observed (+); awaited (-)] and female Chrysomya albiceps $\left(\mathrm{G}_{2}\right)$ [ observed (..); awaited (-), the sexual proportion of 5 male/ 1 female being kept under laboratory conditions $\left(27^{\circ} \mathrm{C}, 60 \pm 10 \%\right.$ UR and $14 \mathrm{hr}$ of photophase).

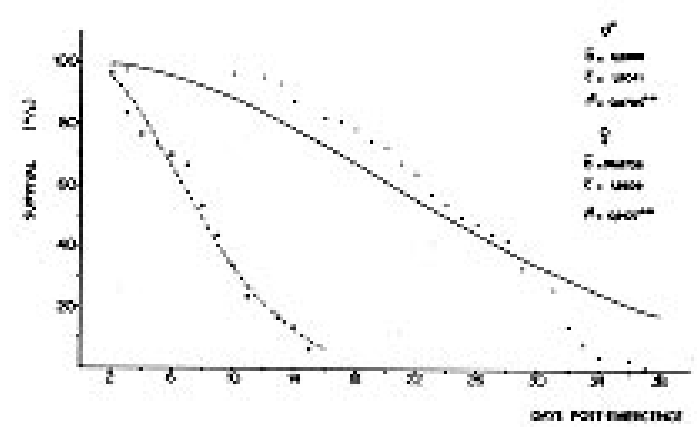

Fig. 9: males survival curve [observed (+); awaited (-)] and female Chrysomya albiceps $\left(\mathrm{G}_{2}\right)$ [ observed (..); awaited (-), the sexual proportion of 1 male/ 3 female being kept under laboratory conditions $\left(27^{\circ} \mathrm{C}, 60 \pm 10 \%\right.$ UR and $14 \mathrm{hr}$ of photophase).

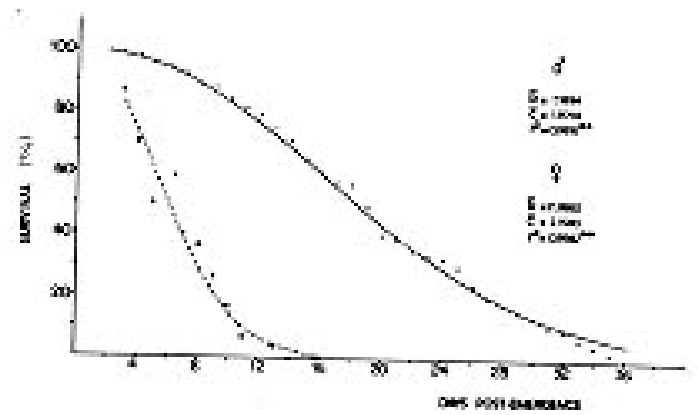

Fig. 10: males survival curve [observed (+); awaited (-)] and female Chrysomya albiceps $\left(\mathrm{G}_{2}\right)$ [ observed (..); awaited (-), the sexual proportion of 1 male/5 female being kept under laboratory conditions $\left(27^{\circ} \mathrm{C}, 60 \pm 10 \%\right.$ UR and $14 \mathrm{hr}$ of photophase).

\section{DISCUSSION}

Copulation of $C$. albiceps confirmed the results obtained by Queiroz and Milward-de-Azevedo (1991) and by Queiroz (1991). These authors, working with this species, in the proportion of one male to one female, maintained at a temperature of $27^{\circ} \mathrm{C}$, observed that the mating started on the 2nd day post-emergence.

This work differed from other studies on the beginning of the oviposition period. Marchenko (1985) ascertained that at $27^{\circ} \mathrm{C}$, C. albiceps females complete maturation of their ovaries five to six days post-emergence. Queiroz and Milward-de-Azevedo (1991) observed that oviposition started on the 5th day post-emergence and the primary peak occurred on the 6th day $(0.045 \mathrm{~g}$ of egg-masses/female) and the secondary on the 9 th day $(0.025 \mathrm{~g}$ of egg-masses/female). Queiroz (1991), working with isolated couples and grouped $C$. albiceps virgin females, under the same laboratory conditions, found that the oviposition started on the 7th and 10th day, respec- 
tively. However, the author reported that this parameter has varied between different experiments conducted under laboratory conditions and observed that this variation occurs on the 6th and 11 th day.

Results of this work did not match with Queiroz and Milward-de-Azevedo (1991) and Queiroz (1991), who found C. albiceps on a 1 male/1female ratio, with a maximum oviposition period of 15 to 20 days, respectively.

Cunha-e-Silva (1990), working with Cochliomyia macellaria (Fabr.), and Fletcher et al. (1966), Mackley and Broce (1981), Hammack (1986), among others, working with Cochliomyia hominivorax (Coq.), reported that the products of microbic activity in the larval substrate, as well as the action of volatile substances the cement of egg-masses, can act as kairomonies, stimulating oviposition by other females of the same species. Thus, the fact that $C$. albiceps adults have been grouped under different sexual proportions soon after emergence, may have inhibited, not only copulation due to competion in seeking a partner for the mating, but also the oviposition of some specimens, thus limiting the estimated average potential. This fact seems to confirm that $C$. albiceps becomes more stimulated for egg-laying under laboratory conditions when grouped in the proportion 1 male/1female, according to the observation by Cunha-e-Silva (1990) with $C$. macellaria.

Taking into consideration all of the sexual proportions utilized in this work, it can be concluded that the exhaustion of the activity of the males and consequently a possible reduction in longevity for adults of both sexes, may be a result of the excessive expenditure of energy on reproductive activities, as observed by Crystal (1967) for $C$. hominivorax. Queiroz (1991), working with grouped virgin females and individual couples of C. albiceps, at $27^{\circ} \mathrm{C}$, observed that the average longevity of the virgin females was 20 days and of males and females whose mating occurred, between 9 and 11.5 days, respectively. However, results of this work show that the greater the number of females in relation to the number of males the shorter their period of survival, and that the opposite did not occur; this suggests that males spend more energy in sexual activities than the females.

\section{REFERENCES}

Avancini RMP 1986. Fases de desenvolvimento ovariano de seis espécies de Calliphoridae (Diptera). Rev Bras Entomol 30: 359-64.

Braack LEO, Retief PE 1986. Dispersal density and habitat preference of the blowflies Chrysomya albiceps (Wd.) and Chrysomya marginalis (Wd.) (Diptera, Calliphoridae). Onderst J Vet Res 53: 1318.

Crystal MM 1967. Longevity of screwworm flies, Cochliomyia hominivorax (Coquerel) (Diptera, Calliphoridae). Effect of sex and grouping. J Med Entomol 4: 479-482.

Cunha-e-Silva SL 1990. Aspectos da Biologia de Cochliomyia macellaria (Fabricius) (Diptera, Calliphoridae), em condições de laboratório. Master Thesis, Universidade Federal Rural do Rio de Janeiro, Itaguaí, RJ, Brasil, 89 pp.

Erzinçlioglu YZ, Whitcombe RP 1983. Chrysomya albiceps (Wiedemann) (Diptera, Calliphoridae) in dung and causing myiasis in Oman. Entomol $M$ Magaz 119: 51-52.

Fletcher LW, O'Grady JJJr, Claborn HV, Grahan OH 1966. A pheromone from male screw-worm flies. $J$ Econ Entomol 59: 142-143.

Gagné RJ 1981. Chrysomya spp., old world blowflies (Diptera, Calliphoridae), recentrly established in Americas. Bull Entomol Soc Am 27: 21-22.

Greenberg B 1971. Flies and disease, vol 1. Ecology, classification and biotic association. Princeton University Press, Princeton, NJ, 856 pp.

Hammack L 1986. Pheromone-mediated copulatory responses of screw worm fly, Cochliomyia hominivorax. J Chem Ecol 12: 1623-1631.

Mackley JW, Broce AB 1981. Evidence of a female sex recognition pheromone in the screw worm fly. Envirom Entomol 10: 406-408.

Marchenko MI 1985. Characteristic of development of the fly Chrysomya albiceps (Wd.) (Diptera, Calliphoridae). Entomol Obozr 64: 79-84.

Queiroz MMC 1991. Aspectos da bioecologia de Chrysomya albiceps (Wiedemann,1819) (Diptera, Calliphoridae), em condições de laboratório. Master Thesis, Universidade Federal Rural do Rio de Janeiro, Itaguaí, RJ, Brasil. 72 pp.

Queiroz MMC, Milward-de-Azevedo EMV 1991. Técnicas de criação e alguns aspectos da biologia de Chrysomya albiceps (Wiedemann) (Diptera, Calliphoridae),em condições de laboratório. Rev Bras Zool 8: 75-84.

Sgrillo RB 1982. A distribuição de Weibull como modelo de sobrevivência de insetos. Ecossistema 7 : 9-13.

Ullerich F 1963. Geschlechtschromosomen ug geschlechtsbestimmung bei einigen Calliphorinen (Calliphoridae, Diptera). Chromosoma 14: 46-110.

Zumpt F 1965. Myiasis in man and animals in the old world. Butterworths, London, 267pp. 
248 Biotic Potential and Longevity of C. albiceps - MMC Queiroz et al. 